\title{
AN ERROR ANALYSIS IN THE USE OF PAST TENSE IN WRITING RECOUNT TEXT AT THE SECOND YEAR STUDENTS OF SMP UNISMUH MAKASSAR
}

\author{
Radiah Hamid and Qayyimah \\ English Education Department, Faculty of Teacher Training and Education \\ Muhammadiyah University of Makassar \\ radiah.hamid@yahoo.com
}

\begin{abstract}
This research aimed to identify the kinds of error in the use of Past Tense in writing recount text and the dominant error made by the Second Year Students of SMP Unismuh Makassar. This research is Case Study Research. The research was conducted in SMP Unismuh Makassar. The population was the Second Year Students in Academic Year 2013-2014. The researcher took Class B1 which consist of 19 students.The instrument used was writing test. Writing test was used to find out the kinds of errors made by the students in writing recount text. By using this instrument, the researcher analyzed detail informations about the errors in the use of Past Tense in writing recount text. The students errors were classified into four categories based on the kinds of error. Those are error of omition with 12 errors, error of addition with 31 errors, error of misformation with 166 errors, and error of misordering with 5 errors. The students made the dominant error in misformation category. It can be seen from the percentage result where misformation were $77,57 \%$, then followed error of addition were $14,48 \%$, error of omition were 5,61\%, and misordering were only 2,34\%. Based on these findings, it can be concluded that the Second Year Students(Class B1) of SMP Unismuh Makassar had many errors in writing recount text. The students should be given intensive exercises in the use of Past Tense in writing recount text. It is quite necessary for the Second Year Students and the English Teacher of SMP Unismuh Makassar to be informed about the result of this research, so they can improve their teaching learning process.
\end{abstract}

Keywords: Error Analysis, recount text, Past Tense, error of misformation.

English is as one of the international language has an important role in international communication. People use language as a means of communication because through language, people can express their thoughts and feeling. Bennet (1968) says that language is the most distinctive of human activities. As a starting-point, language may be thought of in broad terms as having many of the characteristics of a code. In learning process, the students sometimes do not realize that they make mistake because of the ignorance of the grammar. The students sometimes face many difficulties in using tenses. The researcher realized that the mistakes or errors that students made in using tenses especially in past tense need to be analyzed carefully. Norrish (1983) explains that errors as follows : "Errors is systematic deviation from the accepted system of the target language. Mistake is non-systematic deviation from the accepted system of a language being 
learned and it is usually due to human limitation such as tiredness, nervousness, and fatigue". It means that errors may occur because of the limitation of human being in mastering the target language. Errors may occur in all components of language such as grammar. Tenses are needed in English texts. Sometimes students still confuse how to use tense in writing a sentence. As in writing recount text, past tense is very important to describe past time in the text because a recount tells a story or describes a sequence of past events.

The research questions which are posed to be answered in this research are: 1) What kinds of errors in the use of past tense in writing recount text are made by the Second Year Students of SMP Unismuh Makassar?, 2) What is the dominant error in the use of past tense in writing recount text made by the Second Year Students of SMP Unismuh Makassar? The objectives of the study are to find out: 1) The kinds of errors in the use of past tense in writing recount text are made by the students, 2) The dominant error in the use of past tense in writing recount text made by the students.

According to Hornby (1995), writing is the activity occupation of writing for example books, stories or articles. Writing skill is as important as others English skills. Writing is not an easy skill. It needs practice to develop this skill. Writing activity needs a process by which people comprehend what they have see. So it is important for the students to know the nature of writing. To be good writing the students should practice to write and improving vocabulary.. There are five components of writing according to Byrne (1990), they are: a) Content; b) The Language Use; c) The Vocabulary Use; d) The Organization; e) Mechanics.

Since texts are constructed in order to achieve different purposes, they are construct in different ways. Consequently, there are a lot of text types in English. However, they are categorized into two kinds, namely literary text and factual text. Recount as one of the factual texts can be say as the simple text type because it even can be about familiar and every day things or past events. To indicate the participants involve in the text, the use of proper nouns is common. Besides, as the purpose of the text is to tell what happened, descriptive words giving details about who, what, when, and how the event took place are usually used. Again, referring back to the purpose of the text, i.e. telling past events, past tense must be 
utilized. Furthermore, words showing the order of events such as first, next, then, afterwards, finally, etc. are commonly included.

According to Anderson (1997) recount is a piece of text that retells past events, which are usually told in order in which they happened. Getting along with Anderson's idea, Derewianka (1980) states: “In a Recount we reconstruct past experience. A Recount is the unfolding of a sequence of events over time. We are using language to keep the past alive and help us to interpret experience”. He further argues that in order to achieve its purpose i.e. to tell what happen, recount will move through some stages; a) Orientation .b) Event c) Re-orientation. Recount text uses Past Tense. Past tense is the form a verb used to describe actions in the past. Azar (1989: 24-29) explains four forms of past tense as follow:

1. Simple Past;.For example: I walked to school yesterday. If a sentence contains when and has the simple past tense in both clauses, the action in the 'when clause' happen first.For example: I stood under a tree when it began rain.

2. Past Progressive; For example:I was studying at eight o'clock last night. Sometimes the past progressive is used in both parts of a sentence when two actions are in progress simultaneously. For example: While I was studying in one room my house, my brother was having a party in other room.

3. Past Perfect; For example: My parents had already eaten by the time I got home. If before or either is used in sentence, the past perfect is not necessary because the time relationship is already clear. The simple past may be use.For example: After the guests had left, I went to bed.

We often hear that people make a lot of mistakes in their past time and eventually be successful in the future. It may occur in learning a language or a target language. To distinguish between an error and mistake, Ellis (2003) suggest two ways; the first one is to check the consistency of learner's performance. If he/she sometimes uses the correct form and sometimes the wrong one, it is a mistake. However, if he/she always use it uncorrectly, it is called an error. The second way is to ask learner to try correct his/her own deviant utterance. Where he/she is unable to, the deviations are errors; where he/she is successful, they are 
mistake. Richards (1985) says that errors result from incomplete learning and knowledge of learners about target language system. Brown (2000) says that the errors can be observed, analyzed, and classified to reveal something of the system operating within the learner, led to a surge of study of learners' errors, called error analysis. Error analysis is a methodology for dealing with which can be observed, analyzed, and classified to uncover and reveal the incidence, nature, causes, and consequences of unsuccessful language learning for the learners Error analysis may be carried out in order to find out how well someone learns a language; and to find out how well someone knows language; and also to obtain information on common difficulties in language learning. Thus, error analysis is the study and the analysis of the errors made by language learners which function as to give the information on how they learn a language, how well they know the language and what difficulties faced by them in achieving the objective.

By conducting error analysis, hopefully the students' error can be eliminated, so the students' capability in English is improved significantly. Gass \& Slinker (1994) identifies 4 steps followed in conducting an error analysis. They are: 1) Identifying the Errors. 2) Classifying the Errors;. 3) Quantifying the Errors, 4) Analyzing Source of Error. According to Dulay,et.al in James (1998) errors can be classified into four kinds, they are : a). Error of Omition: It is a sentence where an element is ommited, actually it should be presented. Example : I not go to school by bus yesterday. It should be : I did not go to school by bus yesterday. b). Error of Addition, in order words some elements are presented which should not be presented. Example : We do study English three times in a week. It should be : We study English three times in a week. c).Error of Misformation: Misformation is the error of using one grammatical form in the place of another grammatical form. Example : I doesn't know him. It should be : I don't know him. B). Error of Misordering: It is a sentence which its order is incorrect.. Example : She not does come early to school. It should be : She doesn't come early to school. 


\section{RESEARCH METHOD}

In this research, the researcher used Case Study Method. Thomas (2011) offers the following definition of case study: "Case studies are analyses of persons, events, decisions, periods, projects, policies, institutions, or other systems that are studied holistically by one or more methods. The variables of this research were: 1) Kinds of errors in the use of Past Tense in writing recount text made by the Second Year Students of SMP Unismuh Makassar. 2) Dominant errors in the use of Past Tense in writing recount text made by the Second Year Students of SMP Unismuh Makassar. The indicators of this reseach were: 1) Errors of Omition, Addition, Misformation, and Misordering. 2) The dominant error taken from the classification of kinds of error.

The population of this research was the Second Year Students of SMP Unismuh Makassar in Academic Years 2013/2014. This research applied the students from Class B1 of the Second Year in SMP Unismuh Makassar. In this research, the data took by using a writing test. Writing test used to find out the kinds of errors made by the students in writing a recount text. By using this instrument the writer analyzed detail information about the errors in the use of past tense in writing recount text made by the students. The data of this research collected from the students composition. In collecting the data, the researcher took steps as follows: 1) The researcher asked the students to choose the topics. The topic were My Funny Experience and Unforgottable Moment in My Life. 2) The researcher asked the students to write a recount text based on the topic that they have choosen. 3) The researcher submitted the task and analyzed the kinds of error made by the students in writing recount text. 4) The researcher analyzed the task using the criteria based on the table below: 
Table 1: The Criteria of Kinds of Error

\begin{tabular}{|c|c|}
\hline $\begin{array}{l}\text { KINDS OF } \\
\text { ERROR }\end{array}$ & CRITERIA \\
\hline Error of Omition & Element should be presented but it is ommited. \\
\hline Error of Addition & Element should not be presented but it is presented. \\
\hline Misformation & $\begin{array}{l}\text { One grammatical form in the place of another grammatical } \\
\text { form. }\end{array}$ \\
\hline Misordering & Wrongly sequence. \\
\hline
\end{tabular}

(James, 1998)

In this research, the researcher analyzed the data by taking Step of Error Analysis based on Gass \& Slinker (1994) to find the errors made by Second Year Students of SMP Unismuh Makassar.

1. Identifying the Errors; the researcher identified and made list for every errors made by the students in the use of past tense in writing recount text.

2. Classifying the Errors; the researcher classified all errors made by the students into kinds of error in the use of past tense in writing recount text.

3. Quantifying the Errors; the researcher counted the result from the classification in kinds of error to knew the dominant of error in the use of past tense in writing recount text made by the students by using the following formula:

$$
\frac{\text { total of each item }}{\text { total of error }} \times 100
$$

4. Analyzing Source of Errors; it used to correct every errors in the use of past tense in writing recount text made by the students then repaired into the correct sentences.

\section{FINDINGS AND DISCUSSIONS}

As stated in previous chapter, the data sources of this study is the students' writing of recount text. This study revealed that the students commited many kinds of errors in the use of past tense in their written of recount text. It caused the 
students did not really understand about the manner of writing in English, especially in the use of past tense. However, in constructing the sentences, the students already using their existing knowledge in writing English. Norrish (1983) says that error is systematic deviation from the accepted system of the target language. It means that errors may occur because of human factor in mastering the target language such as the limitation of memory, psychological problem and do not understand about the material of subject. In this section, the researcher analyzed the systematic deviation from the accepted system of the target language. As Corder (1973) says that error analysis is the study analysis of the errors made by the foreign language learners to predict the errors or the difficulties in learning foreign language.

1. The Kinds of Errors in the Use of Past Tense in Writing Recount Text.

The first step to analyze the errors, the researcher identified all errors made by the students in the use of past tense in their writing of recount text. Second, the researcher identified the students' errors in the use of past tense in their writing of recount text. After that, the researcher classified all errors into kinds of errors based on James theory (1998). The last, the researcher found the dominant of error based on the result from classification of the students' errors in the use of past tense in writing recount text. Then, the frequency and percentage of errors is presented in order to ease readers understand the data.

a. Identifying the Students' Error.

The following table shows total of the students error in the use of past tense in writing recount text based on kinds of errors.

Table 2: Total Identification of the Students' Error.

\begin{tabular}{|cc|}
\hline TOTAL OF THE STUDENTS & TOTAL OF THE ERRORS \\
\hline 19 & 214 \\
\hline
\end{tabular}

From the table above showed that there are 214 errors made by Class B1 of the Second Year Students at SMP Unismuh Makassar. In analyzing 
the data, the researcher identified the students' errors. After identifying the students errors, the researcher found 214 errors of the students in the use of past tense in writing recount text based on the result of the data from this research. Those identitfication used to find out the kinds of errors which made by Class B1 of the Second Year Students at SMP Unismuh Makassar b. Classifying the Students Errors.

In this section, the researcher classified total numbers of errors that the researcher found by the students writing of recount text. First, the researcher classified the errors in use of past tense:

Table 3: The Total of the Students' Error in the Use of Past Tense

\begin{tabular}{|ccc|}
\hline Simple Past Tense & Past Continous Tense & Past Perfect Tense \\
\hline 212 & 1 & 1 \\
\hline Total of Errors: 214 & \\
\hline
\end{tabular}

From the table above, it shows that the most errors in the use of past tense made by the students was in the use of Simple Past Tense, it was found that there were 212 errors in the use of simple past tense, 1 error in the use of past continous tense, and 1 error in the use of past perfect tense. It is caused mostly students did not know the movement of verb from infinitive into past tense.Then, the researcher classified the errors into kinds of errors.

Table 4: The Total of the Students' Kinds of Error

\begin{tabular}{|lc|}
\multicolumn{1}{|c|}{ KINDS OF ERRORS } & OCCURENCE \\
\hline Error of Omition & 12 \\
\hline Error of Addition & 31 \\
\hline Misformation & 166 \\
\hline Misordering & 5 \\
\hline TOTAL: & $\mathbf{2 1 4}$ \\
\hline
\end{tabular}

1) Error of Omition 
The researcher found 12 errors who ommited from the student's writing test, for example:

- My saw many people *rice planting and pour plant.

It should be: I saw many people were planting rice and pouring plant.

- I *waiting friends to play badminton.

It should be: I was waiting my friends to play badminton.

In the findings, the students didn't exactly understand about the structure of past tenses. For example, sentence no. $1 \& 2$ have to follow the formula of Past Continous Tense in Use 1, where we use the Past Countinous to talk about action or situation that lasted for some time in the past, and whose duration time is unknown or unimpotant

2) Error of Addition

The researcher found 31 errors who presented which should not be presented from the student's writing test, for example:

- *I'm always bath in the morning

It should be: $\underline{I}$ always bathed in the morning.

- When *I'm bath, I'm always brushed my tooth.

It should be: When $\underline{I}$ bathed, I always brushed my teeth

In the findings, sentence no. 1-10, 13, 14, 16-18, 20-24, 26, 27, 30, and 31. In those sentence, the students added word "am" after subject into their sentences where the word "am" can not be used in past tense form.,

3) Misformation

The researcher found 166 grammatical errors of the students in writing recount text, for example:

- When I *arrive, me and my family....

It should be: When I arrived, me and my family...

- My family *meet with my grandmother.

It should be: My family met with my grandmother.

In this case, mostly students did not know the movement verb from infinitive into past tense. For example, sentence no. 1,2,3,4, and 5. In 
those sentences, the students use invinitive verb where the verb should be past tense verb.

4) Misordering

The researcher found 5 misordering in writing recount text made by the students, for example:

- I am *to go sleep.

It should be: I went to slept.

- $\quad$ The mountain are so high and *field rice which spans the eye.

It should be: The mountain was so high and the rice fields that stretched..

In the findings, the students made a sentence which its order is incorrect. For example sentence no. 1,2, and 4. In those sentences, the students put the wrong sequence in their writing of recount text.

2. The Dominant Errors in the Use of Past Tense in Writing Recount Text

The table below shows the percentage from each kinds of errors in the use of Past Tense in writing recount text made by the students.

Table 5: The Percentage of the Students; Kinds of Errors.

\begin{tabular}{|lc|}
\multicolumn{1}{|c}{ KINDS OF ERRORS } & PERCENTAGE \\
\hline Error of Omition & $5,61 \%$ \\
\hline Error of Addition & $14,48 \%$ \\
\hline Misformation & $77,57 \%$ \\
\hline Misordering & $2,34 \%$ \\
\hline TOTAL: & $\mathbf{1 0 0 \%}$ \\
\hline
\end{tabular}

The table above shows the percentage from each kinds of errors, and the researcher concluded that Error of Omition, Error of Addition, and Misordering are only mistakes, as a result of the percentage does not fulfill the minimum standard of errors which at least $35 \%$ from the total of each kinds of errors.

Chart 1: The Students' Dominant Error 


\section{The Students' Kinds of Error}

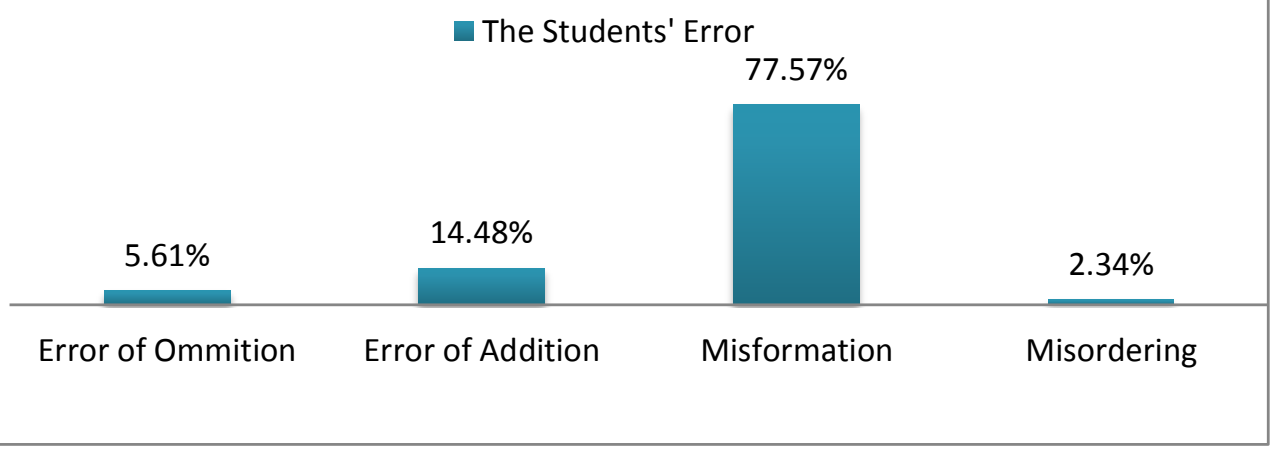

Based on the chart above, error of omition category had 5,61\%, error of addition category had $14,48 \%$, misformation had $77,57 \%$, and misordering had only $2,34 \%$. The data shows that misformation was the dominant kinds of error in the use of Past Tense in writing recount text made by Class B1 of the Second Year Students at SMP Unismuh Makassar.

\section{CONCLUSION AND SUGGESTION}

\section{Conclusion}

1. There are four kinds of errors that found in the use of PastTense in writing recount text by Class B1 of the Second Year Students at SMP Unismuh Makassar. They are error of omition category showed 12 errors in the use of past tense in writing of recount text, error of addition category showed 31 errors in the use of past tense in writing recount text, error of misformation category showed 166 errors in the use of past tense in writing recount text, and error of misordering category showed only 5 errors in the use of past tense in writing recount text.

2. Based on the chart in the findings, the error of misformation category is the dominant errors made by Class B1 of the Second Year Students at SMP Unismuh Makassar with percentage 77,57\%, then followed error of addition category with percentage $14,48 \%$, error of omition category with percentage $5,61 \%$, and the last was misordering category with percentage only $2,34 \%$.

\section{Sugggestion}


Based on the findings of this study, the researcher give some suggestions:

1. For the English Teacher at Second Year of SMP Unismuh, it should be found the better strategy in teaching to determine the ability of students' knowledge and motivate the students to learn tenses,especially Past Tense, so they will be able to reduce their error next. For the students, they should learn more about tenses, more attractive, and active to use them or practice them in their daily conversation to make them more familiar in using tenses.

2. For the next researcher to use these results of this study as the additional reference and comparative study of error research. Since this study is only limited on the kinds and the dominant of errors, it will be more interesting to observe the factors which influence the students to commit those errors. Future research in this field should determine the kinds of error by writing because the certain type of writing may influence the production of errors.

\section{BIBLIOGRAPHY}

Anderson, M. And K. Anderson. 1997. Text Types in English 1 and 2. South Yarra: Macmillan Education Australia pty ltd.

Azar, Betty. Schamper. 1989. Understanding and Using English Grammar. New Jersey: Prentice Hall.

Bennet. 1968. Language and Language Teaching. London: Cambridge University Press.

Brown, H. D. 2000. Principles of Language Learning and Teaching. Longman.Bungin, $\mathrm{H}$.

Byrne, Donn. 1990. Teaching Writing Skills. London and New York: Longman Group UK Limited.

Corder, S.P. 1973. Introducing Applied Linguistic. Middlesex, Penguin.

Derewianka, B. 1980. Exploring How Texts Work. Newton: Primary English Teaching Association. 
Edward, E. Wilson. 2001. Writing and Grammar Communication in Action. USA: Prentice-Hall, Inc.

Eisenhardt. 1989. Building Theories from Case Study Research. Retrieved on September, 2013, from http://ideas.repec.org/a/eee/jbrese/v64y2011i7p680686.html.

Ellis, Rod. 2003. Second Language Acquisition: An Introductory Course. Mahwah, NJ: LEA

Gass, S. and Slinker, L. 1994. Second Language Acquisition: An Introductory Course. Mahwah, NJ: LEA.

Group.Corder, S. Pit. 1981. Error Analysis and Interlanguage. London: Oxford University Press.

James, Carl. 1998. Errors in Language Learning and Use Exploring Error Analysis. New York: Addison Wesley Longman.

Norrish, Jhon. 1983. Language Learner and Their Errors. London: Macmillan Press.

Richards, J.C. 1985. The Context of Language Teaching. America: Cambridge University Press.

Singh, Kumar Y. 2006. Fundamental of Research. Ansari Road. Daryaganj. New Delhi. New Age International Publisher Ltd.

Smalley and Ruette. 1986. Refening Composition Skills. New York: Macmillan Publishing Company.

Talif, R \& M, Edwin. 1989. Error Analysis of Form Four English Compositions. The English Teacher. Vol. XVIII, September 1989.

Thomas. 2011. Qualitative Inquiry. Retrieved September, 2013, from http://en.wikipedia.org/wiki/Case_study\#History_of_the_case_study.

Thompson, A.J and Martinet, A. V. 1986. A Practical English Grammar. New York: Oxford University Press. 